UDK 711.581-168, 643.01

\title{
JUSTIFICATION OF THE TYPES OF OBSOLETE HOUSING STOCK AS THE FIRST STAGE OF EFFECTIVE RECONSTRUCTION
}

\author{
A.M. Pleshkanovska \\ Professor, Dr. habil. of Technical Science \\ D.S. Kuznetsova \\ Assoc. Prof., PhD \\ Kyiv National University of Construction and Architecture \\ 31, Povitroflotsky ave., Kyiv, Ukraine, 03680
}

DOI: $10.32347 / 2410-2547.2021 .107 .193-210$

The complex reconstruction of the obsolete housing stock is an actual problem for many countries. Now this task is an urgent challenge for Ukraine. There is a large number of buildings which condition requires urgent major repair or demolishing in Ukraine.

In order to renew the housing stock at the state level a program for the complex reconstruction of the housing stock is planned. The success of the implementation of housing stock renovation program depends on many conditions. One of the most important barriers is the shortcomings of the legislative framework. The absence and ambiguity of legal provisions governing the implementation of the complex reconstruction make the process of housing rehabilitation difficult and extremely slow.

The experience of Ukraine demonstrates that one of the issues within the implementation of the complex reconstruction program of the housing stock is the justification of criteria for the definition of objects to be reconstructed. he classification of obsolete housing stock objects presented in Ukraine (on the example of Kyiv) has been carried out in the article. In the study several prevailing types of buildings were distinguished: historical buildings, buildings of the Stalin's type («stalinki»), buildings of barrack type and buildings of the first period of industrial house building, the so-called «khrushchevki»

The drawbacks of the existing approach to the definition of outdated housing stock are analyzed. Criteria for defining obsolete housing stock and parameters for their determination are proposed.

The considerable volumes of the obsolete housing stock (about third of the total housing stock) and the lack of the necessary financing require a thorough analysis of the objects of comprehensive reconstruction, starting with a clear parameterization of the criteria for assigning existing housing stock to the obsolete one and determining rational methods of reconstruction depending on the types of obsolete housing stock.

The justification of criteria and parameters for defining the obsolete housing stock allows to make a step forward to the definition of the most efficient types of reconstructive measures for appropriate types of buildings.

Keywords: obsolete housing stock, technical condition, safety of living conditions, comfort of living conditions, effective expectancy life of the building.

Introduction. Settlements, originating in a certain period and at a certain point of space, during the course of their existence gradually turns from a small group of buildings to a large city. The formation of living conditions in the settlement as a kind of reflection and consequence of the gradual development of urban infrastructure, does not always occur at an even pace, but experiences either rapid growth, or a slowdown.

It is possible to distinguish several characteristic periods of the city's existence [17-18]: emergence (creation of primary structural elements of the urban environment); formation (rapid increase in volumes and quality of

(C) Pleshkanovska A.M., Kuznetsova D.S. 
material objects and the level of the urban environment comfort); slowdown (when the quality of urban material and living conditions reaches a certain peak in accordance with the historical socio-economic conditions of society).

The next phase can occur in three scenarios:

1) stagnation - gradual aging and destruction of the material environment and, as a consequence, a rapid decline in the level of comfort in the city);

2) stabilization - permanent maintenance of the quality of the environment and provision of adequate living conditions;

3) development - further development of the quality of the urban environment and living conditions in accordance with the latest evolutionary and technological achievements of mankind.

The main task of local self-government bodies, designers and builders is to prevent the destruction of the city and, at the very least, to ensure a stable level of quality of living in the city and to try to create conditions for its further development. The long-term operation of the objects of material infrastructure necessarily leads to the loss of primary operational characteristics of buildings and structures [2, 5], to their physical [11, 13] and moral [6] wear. The maintenance of the proper quality of residential and non-residential buildings is ensured through the implementation of programs for the reconstruction, renovation, and rehabilitation of obsolete buildings.

In different countries the issue of maintaining the proper state of residential and public buildings is given constant attention both at the theoretical and practical levels $[1,2]$. Reconstruction, renovation or rehabilitation programs are ongoing. In Ukraine, however, there were no mass activities for the reconstruction of the housing stock between 1990 and 2020. Therefore, the problem of the reconstruction of the housing stock is urgent for Ukraine.

According to the State Statistics Service of Ukraine as of January, 2018 the total area of the country's housing stock was 993.3 million sq. m (without taking into account the area of housing stock in the temporarily occupied territories of Ukraine) [25]. At the same time, the housing stock of urban settlements is $60.9 \%$ (599.4 million sq. $\mathrm{m}$ ) from the general stock. Taking into account that $64.9 \%$ of housing stock in Ukraine was built more than 40 years ago the problem of updating the obsolete residential multi-apartment buildings is extremely acute for all Ukrainian cities (see Table 1) [24].

Table 1

Distribution of the housing stock of Ukraine by construction period, \%

\begin{tabular}{|c|c|c|c|}
\hline \multirow{2}{*}{ Period } & \multirow{2}{*}{ Apartments } & \multicolumn{2}{|c|}{ Including in urban areas } \\
\cline { 3 - 4 } & & Apartments & $\%$ \\
\hline Until the 1950 & 7300 & 6200 & 9,5 \\
\hline In the 1950s & 11400 & 8900 & 16,3 \\
\hline In the 1960s & 21800 & 19600 & 26,3 \\
\hline In the 1970s & 25400 & 27700 & 20,9 \\
\hline In the 1980s & 23100 & 26100 & 17,0 \\
\hline After 1990s & 11,0 & 11,5 & 10,0 \\
\hline
\end{tabular}


In 2019, the development of the Program for the Comprehensive Reconstruction of the Obsolete Housing Stock of the City has been started in Kyiv. It necessitated the renewal of the existing regulatory and legal framework and the creation of methodological support for the implementation of the program both in Kyiv and other settlements.

\section{Purpose and methods}

The term obsolete housing stock in Ukraine is widely used both in public speaking and in scientific publications. However, in the legislation this term is used only in one document - the law of Ukraine «On the complex reconstruction of quarters (microdistricts) of the obsolete housing stock» [27]. According to the legislation «obsolete housing stock - is a set of housing objects up to five floors, except for individual houses, which by technical condition do not meet the modern normative requirements of safe and comfortable living, the maximum period of operation of which is expired or the wear of the main structural elements of which is not less than $60 \%$ ». Any other quantitative and qualitative characteristic of this term in the legislativenormative base of Ukraine is absent. In this definition, four criteria sign of an obsolete fund can be distinguished: number of floors, technical condition, safety of living conditions, and comfort of living conditions.

The purpose of this study is to determine the parametric characteristics of the criteria for considering buildings as obsolete ones. The results of this study can be useful in adjusting the existing legal and regulatory framework for the development and implementation of Programs for the comprehensive reconstruction of the obsolete housing stock, as well as developing recommendations for the application of possible reconstruction methods in accordance with various types of obsolete buildings.

The study is based on the application of methods of formalizing the criteria of the obsolete housing stock on the basis of comparative analysis of the regulatory and legal basis and terminology apparatus of the reconstruction processes.

This allows us to identify certain types of obsolete buildings that require urgent reconstruction measures and justify the sequence of reconstruction projects. Besides, analysis of the results of comparative research of implemented foreign and domestic programs and projects of the comprehensive reconstruction of appropriate types of buildings is carried out.

The study was carried out on the basis of statistical reports of the structural unit of the Kyiv City State Administration on the volume and condition of the existing housing stock in Kyiv.

\section{Theory}

In Ukraine the term obsolete housing stock is most often applied to residential development of the first period of industrial housing construction (the 50s-60s of the last century). The total amount of this housing stock in the country is about 72 million sq. $\mathrm{m}$. [24] of which $12.8 \%$ (9,2 million sq. m.) is in Kyiv [12]. However, the typology of residential and non-residential stock, which in its characteristics can be classified as obsolete, is much wider.

Proceeding from the historical stages of the formation of housing development, in the study several prevailing types of buildings in Kyiv were 
distinguished:

- historical buildings. Includes two subtypes: (a) buildings and constructions of historical, architectural and cultural value, which are included in the register of cultural heritage monuments; (b) so-called background buildings, that is, buildings and structures that are not monuments of cultural heritage, but create an idea of the urban environment of a certain historical period of formation;

- buildings of the Stalin's type («stalinki»). An insignificant amount of buildings of increased comfort constructed in the $30 \mathrm{~s}-40$ s of last century (period of Stalin's rule);

- buildings of barrack type. Buildings and constructions of extremely low quality, which were built mainly after the Second World War as a temporary housing stock;

- buildings of the first period of industrial house building, the so-called «khrushchevki». Mostly five-story brick and panel houses, which were built according to the program for the restoration of the housing stock destroyed during the Second World War, started by the head of the USSR Nikita Khrushchev.

Each type of these buildings is characterized by various architectural and planning features, number of floors, material of structural elements and other characteristics (Table 2).

Table 2

Main characteristics of various types of outdated residential buildings

\begin{tabular}{|c|c|c|c|c|}
\hline \multirow[b]{2}{*}{ Parameter } & \multirow{2}{*}{$\begin{array}{l}\text { Historical type } \\
\text { of buildings }\end{array}$} & \multirow{2}{*}{$\begin{array}{l}\text { Barrack type } \\
\text { buildings }\end{array}$} & \multicolumn{2}{|c|}{ «Stalinka» type buildings } \\
\hline & & & ordinary & $\begin{array}{c}\text { 《nomenklatura» } \\
\text {-intended }\end{array}$ \\
\hline series & & & $\begin{array}{c}\text { I-201 - I- } \\
405\end{array}$ & II-01 - II-07 \\
\hline $\begin{array}{c}\text { construction } \\
\text { period }\end{array}$ & before 1920 & $1950 \mathrm{~s}$ & $1950 \mathrm{~s}$ & $1950 \mathrm{~s}$ \\
\hline $\begin{array}{l}\text { load-bearing wall } \\
\text { material }\end{array}$ & brick, wood & $\begin{array}{l}\text { brick (of } \\
\text { destroyed } \\
\text { buildings) }\end{array}$ & brick & Brick \\
\hline $\begin{array}{l}\text { load-bearing wall } \\
\text { thickness, } \mathrm{m}\end{array}$ & $0.51-0.80$ & & 0.51 & 0.51 \\
\hline bridging & wooden & wooden & wooden & $\begin{array}{l}\text { reinforced con- } \\
\text { crete floor slabs }\end{array}$ \\
\hline roof & $\begin{array}{c}\text { sloped, with an } \\
\text { attic }\end{array}$ & \begin{tabular}{|c|}
$\begin{array}{c}\text { sloped, with } \\
\text { an attic }\end{array}$ \\
\end{tabular} & $\begin{array}{l}\text { sloped, with } \\
\text { an attic }\end{array}$ & $\begin{array}{c}\text { sloped, with an } \\
\text { attic }\end{array}$ \\
\hline number of storeys & $1-8$ & $1-2$ & 3 & $5-10$ \\
\hline room height, $\mathrm{m}$ & $2.5-4.5$ & 2.8 & $2.8-3.0$ & $3.3-3.6$ \\
\hline kitchen area, $\mathrm{m}^{2}$ & $4,5-12$ & $\begin{array}{c}6-15 \\
\text { (shared) }\end{array}$ & $7.0-7.8$ & $7-12$ \\
\hline elevator & absent/present & absent & absent & present \\
\hline
\end{tabular}


Continuation of Table 2

\begin{tabular}{|c|c|c|c|c|}
\hline \multirow{2}{*}{ Parameter } & \multicolumn{3}{|c|}{ «Khrushchevka» type 5-storey buildings } & \multirow{2}{*}{$\begin{array}{c}\text { «hrushchevka» } \\
\text { type 9-storey } \\
\text { panel buildings }\end{array}$} \\
\hline & panel & brick & brick / panel & \\
\hline series & $1-464$ & $1-438$ & $1-480$ & $1-464 \mathrm{~A}$ \\
\hline $\begin{array}{l}\text { construction } \\
\text { period }\end{array}$ & $1960 \mathrm{~s}$ & $1950 \mathrm{~s}-1960 \mathrm{~s}$ & $1960 s-1970 s$ & $1960 s-1970 s$ \\
\hline $\begin{array}{l}\text { load-bearing wall } \\
\text { material }\end{array}$ & $\begin{array}{l}\text { reinforced } \\
\text { concrete } \\
\text { panels }\end{array}$ & $\begin{array}{l}\text { brick, brick } \\
\text { large-block }\end{array}$ & $\begin{array}{l}\text { brick, reinfor- } \\
\text { ced concrete } \\
\text { panels }\end{array}$ & $\begin{array}{c}\text { reinforced } \\
\text { concrete panels }\end{array}$ \\
\hline $\begin{array}{c}\text { load-bearing wall } \\
\text { thickness, } \mathrm{m}\end{array}$ & 0.35 & 0.51 & $0.35-0.45$ & 0.35 \\
\hline bridging & $\begin{array}{l}\text { flat-slab, } \\
\text { reinforced } \\
\text { concrete }\end{array}$ & $\begin{array}{l}\text { flat-slab or } \\
\text { hipped, } \\
\text { reinforced } \\
\text { concrete } \\
\end{array}$ & $\begin{array}{l}\text { hipped, } \\
\text { reinforced } \\
\text { concrete }\end{array}$ & $\begin{array}{l}\text { hipped, } \\
\text { reinforced } \\
\text { concrete }\end{array}$ \\
\hline roof & $\begin{array}{l}\text { flat-slab, } \\
\text { combined }\end{array}$ & $\begin{array}{l}\text { flat-slab, } \\
\text { combined }\end{array}$ & $\begin{array}{c}\text { flat-slab, } \\
\text { combined or } \\
\text { separate }\end{array}$ & flat-slab \\
\hline $\begin{array}{c}\text { number of } \\
\text { storeys }\end{array}$ & 5 & 5 & 5 & 9 \\
\hline room height, $\mathrm{m}$ & 2.5 & 2.5 & 2.5 & 2.55 \\
\hline kitchen area, $\mathrm{m}^{2}$ & $5.6-6.3$ & $5-6$ & $5-6.5$ & $6.4-7.6$ \\
\hline elevator & absent & absent & absent & present \\
\hline
\end{tabular}

However, all of these types of buildings are characterized by a long life (from 50 to 150 years) and an urgent need for reconstructive measures. But as already mentioned, in the definition of obsolete housing stock the period of construction and the lifetime of operation are not mentioned.

Let us consider in detail the signs that are applied in the legislative definition of the term obsolete housing stock, and can serve as criteria for considering an existing housing stock as an obsolete one.

\subsection{Number of floors}

According to Article 1 of the Law of Ukraine «On the complex reconstruction of quarters (microdistricts) of the obsolete housing stock» [27], the term obsolete is referred to «... a set of housing objects up to five floors, except for individual building». Considering the types of residential development in Kyiv according to the historical periods of construction, it can be noted that number of floors of buildings built before 1980 is significantly different.

The historical buildings are characterized by the greatest variety. These are the 1-2-floors buildings of the former country houses of wealthy Kyivans, which in the process of the spatial development of the city entered its borders. There are also the 2-3-floors buildings of the most preserved historical district of the city - Podol. There are also 8-9-floors profitable houses of various types 
of prestige in the central historical part of Kyiv. The total volume of this type of construction is about 2.6 million sq. $\mathrm{m}$.

The second type - Stalin's type - depending on the level of comfort of houses is represented by 3-4-floors buildings (with a lower level of comfort) and 7-8-floors buildings (with a higher level of comfort). The construction volume of such buildings is about 0.73 million sq. $\mathrm{m}$.

The buildings of barrack type, which amounts to about 0.28 million sq. $\mathrm{m}$, is in a very poor condition and presented by 1-2-floors buildings predominantly.

The fourth type of buildings is the most widely represented. These buildings refer to the first period of industrial housing construction. They are predominantly 5 -floors buildings with a small number $(0.47$ million sq. $\mathrm{m})$ of 9-floors panel buildings. The total amount of this housing stock is about 9.2 million sq. $\mathrm{m}$.

It is obvious that the definition given in the current legislation explicitly limits objects that can potentially be covered by complex reconstruction projects ignoring objects of housing more than five floors, that does not correspond to the description of the above mentioned types of building.

On this basis, the number of floors cannot be a criterion for assigning buildings to the category of obsolete housing stock which requires immediate reconstructive measures. The number of floors can only be one of the signs according to which it is possible to roughly determine the belonging of a particular type of building to a certain period of construction, and as a consequence, to determine the approximate lifetime of this building and its corresponding physical wear and technical condition.

\subsection{Technical condition}

The technical condition of the object, construction design, engineering system is a set of indicators characterizing the operational suitability of the object in comparison with their maximum permissible values [19]. Technical condition assessment presumes determination of the level of fitness of the technical condition of the object, its constructions and engineering systems based on comparison of the actual values of their characteristics with the values defined by the design and normative documentation. The main characteristic for establishing the general technical condition of the object is an aggregate estimate of the physical wear of its structural elements.

The detailed calculation of physical wear considering the damage of specific structural elements is carried out on the basis of characteristics of damages and indices of the specific weight of structural elements. The specific weight of elements in the replacement cost of a building is taken according to the average parameters of the replacement cost for the building the corresponding functional purpose.

Physical wear is treated as a loss of building value compared to the value of a new building due to partial or complete loss of initial technical and technological qualities of its elements [19]. Therefore, the amount of physical wear can be determined by calculating the necessary costs to eliminate physical wear. 


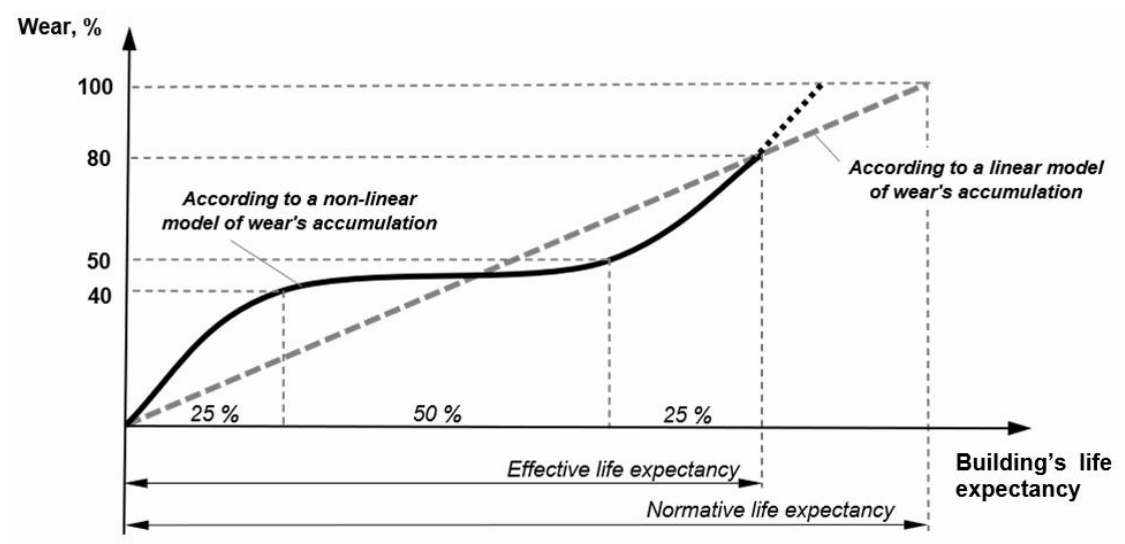

Fig. 1. Dynamics of physical wear during different periods of effective life expectancy

When determining physical wear on the basis of the building's lifetime the method of a residual lifetime is used. It presumes the comparison of the chronological and normative life of the building. The normative term of building operation depends on the group of solidity, which in turn is determined by the features of the structural elements of the building - the material of the walls (stone, brick, large-panel, large-block, small natural or artificial stones, wooden and other), type of overlap (reinforced concrete prefabricated or monolithic, metal, wooden and others), the presence and characteristics of engineering equipment. There are six solidity groups with an average building lifetime according to normative in Ukraine: I - 150 years; II 125 years; III - 100 years; IV - 100 years; V - 70 years; VI - 30-50 years [19]. Figure 1 shows a normatively defined model of the linear dependence of physical wear on the duration of operation of the building (dotted line).

\subsection{Safety of living conditions}

After reconstruction or major repairs, residential buildings must be restored to their functional purpose and basic requirements for them throughout the subsequent period of operation. These requirements imply compliance with certain indicators [22].

They can be divided into three groups. The first group includes indicators that characterize the safety of living conditions in a residential building (the strength, stability and reliability of the building, fire safety requirements). The second group includes indicators characterizing the comfort of living conditions (the necessary level of comfort and sanitary condition of the house and the adjacent areas; the normative level of noise protection; the normative insolation of the building). The third group includes indicators characterizing the efficiency of the operation of a residential house (normative indicators of heat protection and energy saving).

Consider the first group. In accordance with the Law of Ukraine «On the complex reconstruction of quarters (microdistricts) of the obsolete housing stock» [27] as one of the criteria for determining the objects of the obsolete 
housing stock, safe living conditions are indicated. They are based on the maximum period of building operation or on the quantitative indicator of the physical wear of the main structural elements of the building $(60 \%)$. This criterion is directly related to the previous one - the technical condition of the object.

Let us consider the concept of the maximum period of building operation. The regulatory framework does not contain the definition of the maximum period of building operation. But there is a concept of the limit building condition - a condition in which further exploitation of the building is inadmissible, connected with difficulties or is not expedient [22]. And there is also the concept of the building's lifetime. Obviously, the determination of the maximum period of building operation refers to the period of building operation before the limit building condition appears.

It is worth noting that two buildings of the same group of solidity of the same construction time (and thus the same chronological life) can have different physical wear. A large number of factors affect the rate of accumulation of physical wear of the building. Physical wear can be the result of natural and/or artificial factors. At the same time, factors affecting physical wear can be divided into internal and external factors in relation to the object $[4,26]$.

Important factors affected the accumulation of physical wear of the building are:

- quality of project documentation;

- quality of building materials;

- observance of technological processes in construction, temperature regimes, technology of preparation and execution of separate stages of construction;

- observation of the maintenance conditions, including the frequency and quality of ongoing and major repairs;

- the duration of periods in which the buildings were unused.

Therefore, in order to take into account the above factors affecting the rate of accumulation of physical wear, the concept of effective life expectancy is introduced (Fig. 1). Depending on the natural conditions and features of the technical operation of the building, its effective life expectancy can differ from a lifetime. Therefore, when determining the physical wear by the method of a residual lifetime without taking into account the peculiarities of technical operation, it is possible to obtain a result that will incorrectly characterize the actual condition of the building.

Understanding the features of accumulation of physical wear of a building is important not only for the correct determination of physical wear, but also for determining those restorative measures that can prolong the building lifetime.

Consider the features of physical wear formation depending on the conditions of use, different periods of building's life, as well as the relationship 
between the level of physical wear and the costs necessary to eliminate physical wear.

In addition, the dynamics of physical wear accumulation varies depending on the period of building operation. It is noted that physical wear accumulates most intensively in the first 20-30 years and after 90-100 years of operation (for houses 1-2 groups of solidity) [2].

There are 3 phases in the period of effective life expectancy [29] (Fig. 1):

- the first phase (cover first $25 \%$ of the effective life expectancy) is characterized by a clear increase in physical wear due to defects caused by the quality of materials and structures, as well as construction and assembly works;

- the second phase (occurs after the first phase and is about $50 \%$ of the effective life expectancy) is characterized by the fact that the process of accumulation of physical wear of the building is sharply slowed down mainly due to repairs;

- the third phase is characterized by a sharp increase in physical wear due to the accumulation of operational fatigue. The building may require complete renovation.

Due to the fact that the technical condition of the building is inversely proportional to its physical wear, it is possible to apply this connection to the overall preliminary assessment of the technical condition of the object. If we use this common model of wear dynamics on the effective life expectancy of different types of buildings according to their types of solidity, we can observe that the actual exploitation term of some types of buildings in Ukraine is exceeded. At the same time, some types of buildings are within their third phase of effective life expectancy (Fig. 2).

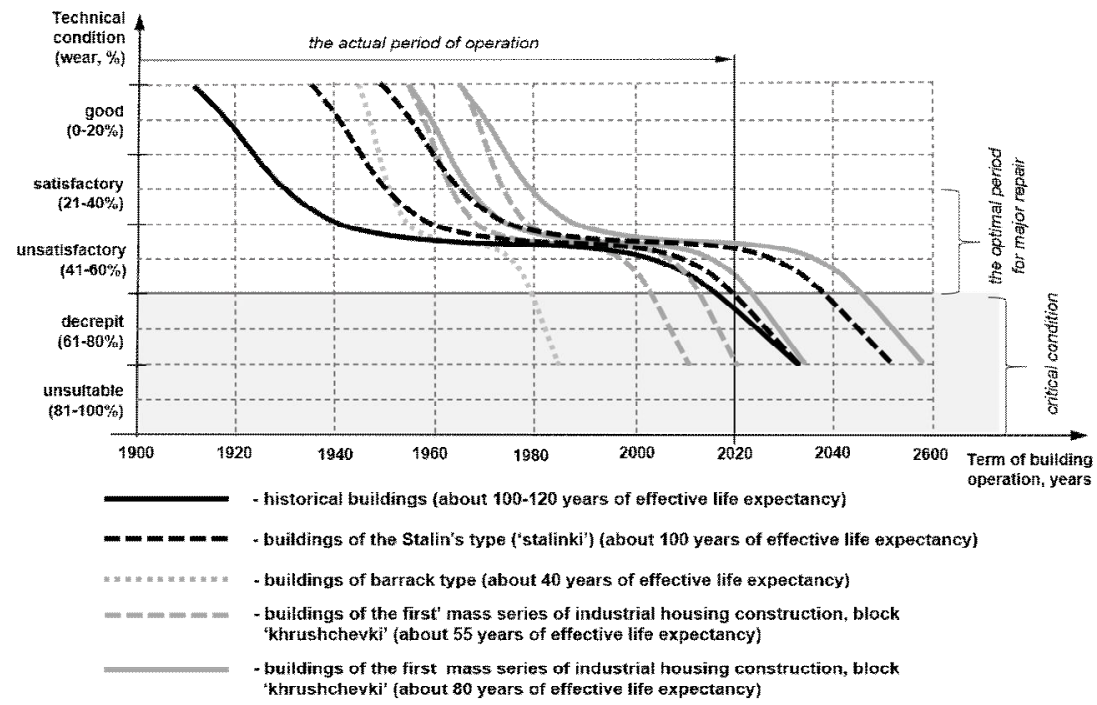

Fig. 2. Dynamics of physical wear and effective life expectancy for buildings of different types which were built in different periods 
The analysis allows us to state that at the time of assessment (approximately - 2020) barrack-type buildings, parts of historical buildings, and buildings of the first mass series of industrial housing construction (panel «khrushchevki») has a completely exhausted period of effective use. These buildings are in disrepair condition.

Some of the buildings constructed in the 1930s («stalinki») and brick «khrushchevki» constructed at the beginning of the first period of industrial housing are in critical condition and need an immediate major repair.

Only the «stalinki» of the 1940s and the brick «khrushchevki» of the 1960s and 1970s still have a margin of safety, but their reconstruction is the most expedient and effective at the current stage.

This analysis is theoretical. Certainly, some groups of buildings were the objects of major repair during their term of exploitation, which significantly affects the extension of the effective life expectancy of the object.

Frequency and quality of ongoing and major repairs affect the rate of accumulation of physical wear. The purpose of the ongoing and major repairs is different. Ongoing repairs are carried out to maintain building condition in a systematic and timely manner and to prevent premature wear of structures and engineering equipment. Major repairs are carried out to restore its resource, replace, if necessary, structural elements, systems of engineering equipment, as well as improving its performance [23]. Ongoing repairs are carried out between major repairs.

Carrying out major repairs can significantly influence the rate of accumulation of physical wear slowing it and prolonging the building's lifetime for dozens of years $[1,16]$.

The exact time for major repairs is difficult to specify since much depends on the actual condition of the building. But the construction norms provide for standard terms, which are indicative terms of service of certain structural elements. For example, the heating system needs to be replaced after 30-40 years. Water supply and sewerage are designed for 25 years of service. The wooden floors, doors, frames and other wooden constructions are estimated for the same period. Therefore, complex repairs with replacement of engineering communications in buildings of all types should be carried out every 30 years, and selective - every 15-20 years. Changing the floors and non-capital walls is recommended after 50 years. During the major repair of buildings, physical wear is eliminated in replaceable structures and just decreases in nonreplaceable ones, since repairs for non-replaceable structures are of a restorative nature.

The efficiency of major repairs depends on the condition of the building. The absence of timely restoring of the structural components' bearing capacity reduces the effectiveness of further refurbishment work. With physical wear up to $40 \%$, the estimated cost of physical wear elimination is about $10-30 \%$ of the cost of the structural components. With further increases in physical wear (40$60 \%$ ), the estimated cost of work increases to $40-80 \%$ of the cost of structural elements, and with wear above $60 \%$ reaches $90-120 \%$ of the cost of structural 
elements. Therefore, the need for systematic repair and restoration works during the building's term of operation is obvious.

\subsection{Comfort of living conditions}

The criterion of «comfort of living condition» has the most ambiguous interpretation, since the essential component of this concept is the subjective attitude of residents to the idea of «comfortable conditions» [9].

In Ukraine housing in terms of comfort and social orientation is divided into two categories [20]:

- first housing category - dwelling with limited lower and unlimited upper limits of areas of apartments and single apartment houses, providing the level of comfort not less than minimum one;

- second housing category - dwelling with limited lower and upper limits of apartments and rooms of dormitories in accordance with the current sanitary standards providing a minimum acceptable level of living comfort.

The requirements for noise protection of both internal premises and nearhouse residential areas, clearly parameterized in the regulatory framework. The maximum permissible noise load parameters are $40 \mathrm{DBA}$ and $30 \mathrm{DBA}$ in the internal premises of apartments and 55 DBA and 45 DBA in the near-house territories day and night respectively [21].

The determination of the insolation mode of the internal rooms and the adjacent areas is carried out by means of a clear parameter -2.5 hours of direct solar radiation, which should provide minimum necessary sanitary and hygienic indicators. These parameters are clearly determined and unified for the housing of any comfort category. It is much more difficult to determine the quantitative indicators of other qualitative characteristics of comfortable housing. They can include: features of the layout of the apartment, the availability of engineering sanitary equipment, the presence of elevators, the height of the premises, the material of structural elements and elements of decoration, etc. [10].

The absence or insufficiency of all the above characteristics can be determined by such a concept as moral wear of the building, that is, the discrepancy of architectural and design solutions, level of internal improvement and engineering equipment with the current technical conditions and norms and the growth of the population's needs [7].

The signs of moral wear of residential buildings include the lack of central heating, water supply, sewerage, elevator, gas supply, obsolete types and designs of this equipment; inconvenient layout, 'passageways' rooms, combined bathrooms, minimum kitchen areas and utility rooms; nonconformity of wall structures, ceilings, stairs and other elements to modern requirements of heat resistance, sound insulation, waterproofing, etc. The moral wear of the building changes intermittently as social demands change. According to experts, this occurs every 8-10 years. Moral wear is formed independently of physical and often develops faster than physical wear.

A separate group of comfort parameters is made up of energy-saving and energy efficiency indicators of the building $[3,15]$. Unfortunately, this 
indicator is absent in the current legislation on the reconstruction of obsolete housing and must be included as a criterion for determining the need for reconstruction measures. Energy efficiency is an indicator characterized by the ratio of efficiency from use to energy consumption [14]. It is a question of the costs of electricity, heat, water, gas, etc. In addition, the indicators of the thermal technical characteristics of the fencing structures are important.

The economically feasible level of energy efficiency is determined by financial and macroeconomic calculations, which grounds the reasonable minimum requirements for energy efficiency. Cost-effective energy efficiency is determined by cost-benefit analysis, and presume that benefits exceed costs by at least $15 \%[15]$.

\section{Result and discussion}

The problem of updating housing stock is extremely urgent for most cities in Ukraine. The long term of building operation, the unsatisfactory technical condition of buildings, and moral wear require urgent measures to improve the level of safety and reliability, technical-operational and energy-efficient indicators of existing buildings, providing modern comfortable living conditions.

The considerable volumes of the obsolete housing stock (about two-thirds of the total housing stock) and the lack of the necessary financing require a thorough analysis of the objects of comprehensive reconstruction, starting with a clear parameterization of the criteria for assigning existing housing stock to the obsolete one and determining rational methods of reconstruction depending on the types of obsolete housing stock.

The basis of such decisions is the current Ukrainian legislative and regulatory framework, which, unfortunately, is not perfect. The wording of the term «obsolete housing stock» in legislation does not provide a sufficiently correct definition of the object of reconstruction. The research has made it possible to define the main values of the parameters of assigning buildings to the obsolete ones by four criteria - number of floors, technical condition, safety living conditions, the comfort of living conditions (Fig. 3).

The existing housing stock of Ukraine, two-thirds of which was built more than sixty years ago, is characterized not only with a significant variety of architectural and design solutions but also different floors - mainly from 2 to 9 floors. In addition, such a number of floors is characteristic of any period of housing construction, including modern. That is why, in our opinion, the floors should not be a criterion for the aging of the housing stock and should be removed from its definition.

The following criteria - technical condition and closely related safety of living conditions - are the most decisive in the determination of the reconstructive measures. Taking into account the characteristics of the structural elements and the corresponding group of solidity, residential buildings built before the 1970s of the last century (first of all, these are panel buildings of the first mass series of industrial housing construction and barrack type houses) have a life limit of $50-100$ years [19]. 


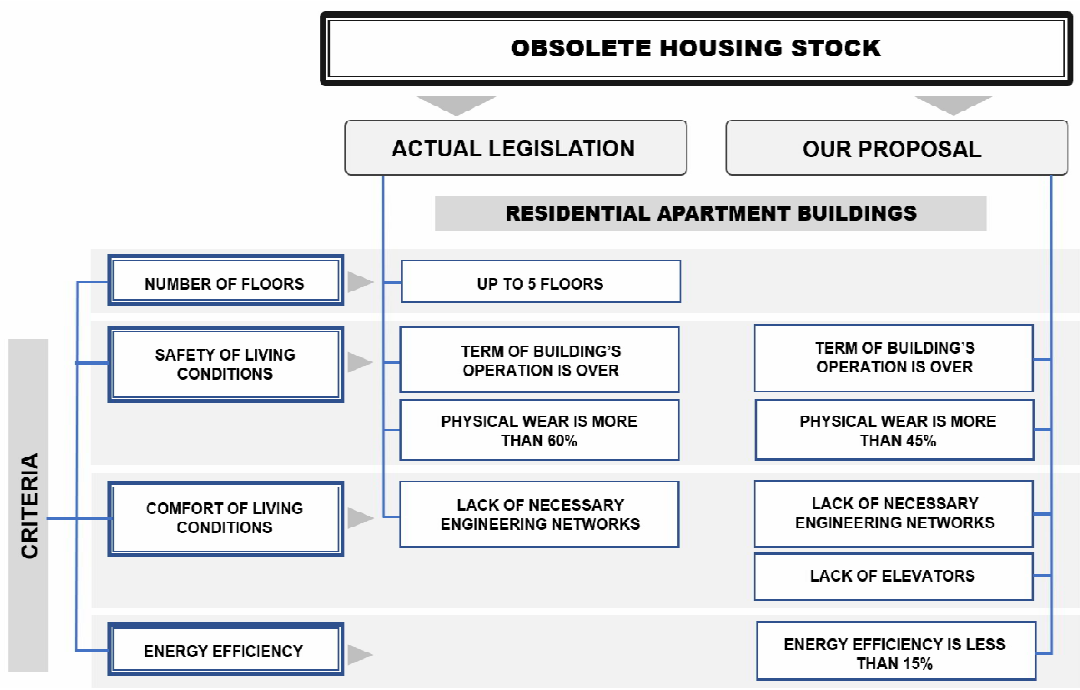

Fig. 3. A comparison between an existing concept of an obsolete stock and our proposal

Thus, a significant part of them is already in the third phase of their lifetime (physical wear more than 50\%), which is characterized by a rapid increase in the rate of accumulation of physical wear through operational fatigue.

One way or another, but as the operating time increases, the level of physical wear increases and at a certain stage the cost of eliminating physical wear can exceed the residual value of the building. This occurs after physical wear reaches $50 \%$. Consequently, the reconstruction of the building before it receives significant physical wear corresponding to the old or not applicable condition is more effective. This allows, on the one hand, to prolong significantly the building lifetime, on the other hand, it allows in most cases to carry out reconstruction, including the improvement of the technical and economic indicators of the building, without the eviction of residents.

Physical wear exceeding 50\% makes it possible to assume that the building is already in poor technical condition and should be included in the major repair program. The absence of reconstruction measures will inevitably lead to an emergency condition of the building, followed by destruction and threat to the lives of residents.

Thus, we believe that this indicator of physical wear (40\%) in the conditions of additional existence of moral wear, that is, the discrepancy of buildings with modern requirements of comfort to residential buildings, which is obvious in relation to the housing of the above-mentioned years of construction, is enough to consider them as objects of obsolete housing stock requiring immediate reconstructive measures.

In this case, we believe that the physical wear indicator at $60 \%$ for the reference of the object to the obsolete housing stock is too high. From the above-mentioned reasons, it is clear that physical wear exceeds $60 \%$ indicates 
the low efficiency of carrying out further reconstruction work for this building. Residential buildings with physical wear over $60 \%$ are potential objects for demolition with the subsequent construction of new residential buildings on this site. At the same time, demolition and new construction require mandatory eviction of residents and significantly complicates work on the comprehensive reconstruction of obsolete buildings.

Non-compliance with previously constructed buildings with modern requirements of comfort cannot always be eliminated in the process of carrying out reconstructive measures. First of all, these are features of the architectural and planning solutions of apartments, the height of premises, level of insolation (which, by the way, is not normalized in many countries of the world). These characteristics, even after reconstruction, remain usually unchanged and will only determine the attractiveness of this housing and its price in the real estate market.

A single legislative parameter of comfort is the area of apartments, or more precisely, its limited lowest meaning. But it is more correct to refer not to the area, but to the housing provision, which is defined as the amount of the total area of the apartment which falls on one resident. In Ukraine, as of January, 2018 the average housing provision is 23.7 sq. m per person [25]; and in Kyiv - 21.8 sq. $\mathrm{m}$ per person [12]. This indicator differs significantly in different settlements of Ukraine and is much lower than in other countries in Europe. In our opinion as a fixed parameter of the minimum guaranteed housing provision the sanitary norm of free privatization of residential premises, fixed in the normative documentation, can be used - $21 \mathrm{sq}$. $\mathrm{m}$. per person [28].

In our opinion in terms of the minimum standard of comfort of living the energy efficiency of buildings operation is the determining factor. It is the excess of the received level of benefits (energy efficiency) above the level of costs for its achievement more than $15 \%$ should be the criterion for the decision to modernize the building.

\section{Conclusion}

In view of the above, we note that it is advisable to consider a comprehensive reconstruction as a long process, which consists of several stages. At each stage, the concept of an obsolete housing stock subject to reconstruction can be changed. Initially, the reconstruction should cover a housing stock with a worse technical condition. Therefore, the main criterion for assigning the object to an obsolete housing stock is the significant physical wear of buildings ( $50 \%$ or more).

The task of reconstruction of the housing stock is not only the technical upgrading but also the improvement of the living conditions of the population, reduce operational costs. So the second stage of the comprehensive reconstruction should cover buildings that have less physical wear indicators ( $40 \%$ or more) but are obsolete in terms of compliance with modern requirements to housing, that is, are not energy-efficient and have significant signs of moral obsolescence. 
On the basis of the above, we propose the following definition of the obsolete housing stock for the comprehensive reconstruction on the first stage - a set of apartment buildings which technical condition does not meet the minimum normative requirements of safe and comfortable living, which average physical wear revealed as a result of the technical survey is not less than $50 \%$.

Definition of obsolete housing stock for comprehensive reconstruction on the second stage - a set of apartment buildings, which technical condition does not meet the minimum normative requirements of safe and comfortable living, which average physical wear is not less than $40 \%$, and energy efficiency is less than $15 \%$.

Revealing the criteria which allow identifying objects of obsolete housing stock, setting the normative parameters of these criteria provides the necessary background for the most effective planning and implementation of the complex reconstruction program according to the needs of the population in the condition of a restricted budget.

Two stages program of complex reconstruction allows eliminating the risk for population connected with the buildings which are in the worst technical condition within the first stage of the program and covering the buildings with better technical but outdated moral conditions within the next stage of the program.

\section{REFERENCES}

1. Abeleshov $V$. Tekhnichna expluatatsyiya budivel. [Technical maintenance of buildings] Kharkiv: KNAMG. - 2009.

2. Baryshikov A. Tekhnichna ekspluatatsiya budivelnykh ta miskykh terytoriy. [Technical operation of buildings and urban areas.] - High School: Kyiv. - 2000.

3. Grabovyy K., Kiseleva E. Energy efficiency of housing stock as an incentive the performance of real estate objects // Proceedings of Moscow State, Vestnik MGSU. - 2015. - № 3. - P.79-91.

4. Kallaos $J$. Explicit consideration of time in the life cycle assessment of buildings. SB10 Finland: Sustainable Community - building SMARTTM Conference Proceedings, Helsinki. - 2010.

5. Kalinin $V$., Sokova C. Otsinka tekhnichnoho stanu zdaniy. [Assessment of the technical condition of the buildings]. INFRA-M: Moscow. -2005.

6. Klyushnichenko E. Sotsialno-ekonomichni osnovy planuvannya ta zabudovy mist [Socioeconomic bases of city planning and development], Kyiv: Ukrhbudinform. - 1999.

7. Klyushnichenko E. Formuvannya zhytlovoho seredovyshcha: Navchalnyy posibnyk. [Forming a housing environment: a tutorial]. 2006. - Kyiv: KNUCA.

8. Kohler N., Steadman P., Hassler U., Research on the building stock and its applications. Building Research and Information. - 2009. - № 37. - P. 449-454.

9. Kovalevska $O$. Housings terms in system of descriptions of life quality. Public Administration: Improvement and Development. - 2011.

10. Krivosheev $P$. Naukovo-tekhnichni problemy resursu budivelnykh konstruktsiy pry rekonstruktsiyi zhytlovykh budynkiv // Reconsructsiya zhitla [Naukovo-tekhnichni problemy resursu budivelnykh konstruktsiy pry rekonstruktsiyi zhytlovykh budynkiv]. - 2009. - №11 . - P. 20-25.

11. Kuznetsova $D$. Otsenka fizicheskogo iznosa podrabatyvayemykh zdaniy po stepeni deformatsiy zemnoy poverkhnosti // Naukovi pratsi DonNTU [Assessment of physical deterioration of undermined buildings by the magnitude of deformations of the earth's surface]. -2009 . - № 6 (125). - P. 69-77.

12. Holovne upravlinnya statystyky Ukrayiny. Zhytlovyy fond Kyyeva [Main Department of Statistics in Kyiv. Housing stock of Kyiv.] - 2019.

13. Meshechek V. V., Matveev E.P. Posobiye po otsenke fizicheskogo iznosa zhilykh i obshchestvennykh zdaniy [Handbook for assessing the physical wear of residential and public buildings]. - 1999. - Moskow: MGSU.

14. Ministerstvo rehionalnoho rozvytku Ukrayiny. Metodika viznachennya yekonomíchno dotsílnogo rívnya yenergetichnoí yefektivnosti budível. [Methods for determining the economically feasible 
level of energy efficiency of buildings Methodology], Kyiv, Ukraine. - 2018. Access mode: https://zakon.rada.gov.ua/laws/show/z0823-18\#n14

15. Oliynyk $O$., Murgul $V$. Strategy for energy efficient reconstruction of residential low-rise buildings, Construction of unique buildings and constructions. - 2016. - 1(40). - P. 112-124.

16. Power A. Housing and sustainability: demolition or refurbishment? Proceedings of the Institution of Civil Engineering: Urban Design and Planning. - 2010. - № 163(4). - P. 205-216.

17. Pleshkanovska A. Metodolohiya kompleksnoyi rekonstruktsiyi mista [Methodology of Complex Reconstruction of the City]. The scientific world, Kyiv. - 2013.

18. Pleshkanovska A., Savchenko O. Horoda i epokhy [Epochs and Cities]. 2nd ed. Kyiv: Logos. 2019.

19. Ministerstvo rehionalnoho rozvytku Ukrayiny. Zhytlovi budynky. Pravyla vyznachennya fizychnoho znosu zhytlovykh budynkiv 75.11-35077234. [Residential buildings. Rules for determining the physical wear of residential buildings, Standard of housing and communal economy of Ukraine]. - 2009. Access mode: https://dbn.co.ua/load/normativy/61-1-0-931

20. Ministerstvo rehionalnoho rozvytku Ukrayiny. Zhytlovi budynky. Osnovni polozhennya DBN V. 2.2-15:2019 [Residential buildings. Basic provisions], Kyiv, Ukraine. -2019.

21. Ministerstvo rehionalnoho rozvytku Ukrayiny. Protect areas, buildings and structures from noise, State building codes, V.1.1-31:2013 [Zakhyst terytoriyi, budynkiv i sporud vid shumu], Kyiv, Ukraine. -2014.

22. Ministerstvo rehionalnoho rozvytku Ukrayiny. Zahalni pryntsypy zabezpechennya nadiynosti ta konstruktyvnoyi bezpeky budivnytstva ta sporudy DBN V.1.2-14-2018 [General principles for ensuring the reliability and structural safety of buildings and structures, State building codes]. Kyiv, Ukraine. -2018.

23. Ministerstvo rehionalnoho rozvytku Ukrayiny. Zhytlovi budynky. Rekonstruktsiya ta kapitalnyy remont DBN V.3.2-2-2009 [Residential buildings. Reconstruction and major repair. State building codes], Kyiv, Ukraine, - 2009. (Міністерство регіонального розвитку України. Житлові будинки. Реконструкція та капітальний ремонт / Zhytlovi budynky. Rekonstruktsiya ta kapitalnyy remont) Access mode: https://dbn.co.ua/load/normativy/dbn/1-1-0-333.

24. Derzhavna sluzhba statystyky. Dity, zhinky ta simya v Ukrayini [Children, females and family in Ukraine, Statistical collection], Kyiv, Ukraine, - 2018. Access mode: http://ukrstat.gov.ua/druk/publicat/kat u/2018/zb/09/DJS 2018 pdf.pdf.

25. Derzhavne upravlinnya statystyky $v$ Ukrayini. Zhytlovyy fond Ukrayiny [Housing stock of Ukraine], - 2019. Access mode: http://www.ukrstat.gov.ua/operativ/operativ2007/zf/zf u/ 2006 u.htm.

26. Thomsen A., Flier $K$. Obsolescence and the end of life phase of buildings. Management and Innovation for a Sustainable Built Environment. Amsterdam, - 2011. Access mode: https://repository.tudelft.nl/islandora/object/uuid\%3A90813327-f8ff-4053-bf10-17cf7c358a3d

27. Verkhovna Rada of Ukraine. Pro kompleksnu rekonstruktsiyu kvartaliv (mikrorayoniv) zastariloho zhytlovoho fondu 525-V, 22 December 2006, Kyiv, Ukraine. [On the complex reconstruction of quarters (microdistricts) of the obsolete housing stock. Law of Ukraine] (Access mode: https://zakon.rada.gov.ua/laws/card/525-16.

28. Verkhovna Rada of Ukraine. Pro pryvatyzatsiyu derzhavnoho zhytlovoho fondu) 2483-XII, 19 June 1992 [On the privatization of the state housing stock. Law of Ukraine], Kyiv, Ukraine. Access mode: https://zakon.rada.gov.ua/laws/show/2482-12

29. Zemtsova $O$., Volodin $W$. Osnovnyye aspekty otsenki iznosa zdaniy [Basic aspects of building wear assessment], Ecology. - 2015. - № 23. - P. 51-56.

Стаття надійшла 23.06.2021

\section{Алла Плешкановська, Дар'я Кузнецова}

\section{ОБГРУНТУВАННЯ ТИПІВ ЗАСТАРІЛОГО ЖИТЛОВОГО ФОНДУ ЯК ПЕРШИЙ ЕТАП ЕФЕКТИВНОЇ РЕКОНСТРУКЦІЇ}

Комплексна реконструкція застарілого житлового фонду є актуальною проблемою для багатьох країн світу. Наразі це завдання $є$ надзвичайно актуальним сучасним викликом для України, адже в Україні існує велика кількість будівель, стан яких вимагає термінового капітального ремонту або, навіть, знесення.

3 метою оновлення житлового фонду на державному рівні планується розроблення програм комплексної реконструкції застарілого житлового фонду. Успіх реалізації реконструкції житлового фонду залежить від багатьох умов. Однією 3 найважливіших перешкод $\epsilon$ 
недосконалість законодавчої бази 3 цього питання. Відсутність та неоднозначність законодавчих норм, що регулюють визначення об'єкту та здійснення комплексної реконструкції, ускладнює та вкрай вповільнюють процес реалізації реконструкції застарілого житлового фонду.

Одним із завдань підготовки програм і проектів комплексної реконструкції житлового фонду є обгрунтування критеріїв визначення об'єктів, що відносяться до того чи іншого типу застарілого житлового фонду. У статті проведено класифікацію застарілих житлових будинків, представлених в Україні (на прикладі міста Києва). У дослідженні було виділено кілька переважаючих типів будівель, а саме: будівлі історичного типу, будівлі сталінського періоду будівництва (так звані «сталінки»), будівлі барачного типу та будівлі першого періоду промислового домобудування, так звані «хрущовки»

Проаналізовано недоліки існуючого підходу до визначення застарілого житлового фонду. Запропоновано критерії віднесення житлового фонду до застарілого та параметри їх визначення.

Значні обсяги застарілого житлового фонду (близько третини загального житлового фонду) та відсутність необхідного фінансування вимагають коригування чинної законодавчої бази 3 цього питання 3 метою ретельного аналізу потенційних об'єктів комплексної реконструкції, та визначення раціональних методів реконструкції заходів залежно від встановлених типів застарілого житлового фонду.

Обгрунтування критеріїв та параметрів для визначення застарілого житлового фонду дозволяє зробити крок вперед до успішної реалізації програм комплексної реконструкції застарілого житлового фонду.

Ключові слова: застарілий житловий фонд, технічний стан, безпечні житлові умови, комфортність житлових умов, очікуваний корисний строк служби будівлі.

\section{Плешкановская А.М., Кузнеиова Д.С.}

\section{ОБОСНОВАНИЕ ТИПОВ УСТАРЕВШЕГО ЖИЛОГО ФОНДА КАК ПЕРВЫЙ ЭТАП ЭФФЕКТИВНОЙ РЕКОНСТРУКЦИИ}

Комплексная реконструкция устаревшего жилого фонда является актуальной проблемой для многих стран мира. Сейчас эта задача стала чрезвычайно актуальным вызовом для Украины, ведь в Украине существует большое количество зданий, состояние которых требует срочного капитального ремонта или даже сноса.

С целью обновления жилищного фонда на государственном уровне планируется разработка программ комплексной реконструкции устаревшего жилого фонда. Успех реализации реконструкции жилого фондыа зависит от многих условий. Одним из важнейших препятствий является несовершенство законодательной базы по этому вопросу. Отсутствие и неоднозначность законодательных норм, регулирующих определение объектов и осуществления комплексной реконструкции, усложняет и крайне замедляющие процесс реализации реконструкции устаревшего жилого фонда.

Одной из задач подготовки программ и проектов комплексной реконструкции жилого фонда является обоснование критериев определения объектов, относящихся к тому или иному типу устаревшего фонда. В статье проведена классификация устаревших жилых домов, представленных в Украине (на примере города Киева). В исследовании было выделено несколько преобладающих типов зданий, а именно: здания исторического типа, здания сталинского периода строительства (так называемые «сталинки»), здания барачного типа и здания первого периода промышленного домостроения, так называемые «хрущевки»

Проанализированы недостатки существующего подхода к определению устаревшего жилого фонда. Предложены критерии отнесения жилого фонда к устаревшему и параметры их определения.

Значительные объемы устаревшего жилого фонда (около трети общего жилого фонда) и отсутствие необходимого финансирования требуют корректировки действующей законодательной базы по этому вопросу с целью тщательного анализа потенциальных объектов комплексной реконструкции и определения рациональных методов реконструктивных мероприятий в зависимости от установленных типов устаревшего жилого фонда.

Ключевые слова: устаревший жилой фонд, техническое состояние, безопасные жилищные условия, комфортность жилищных условий, ожидаемый эффективный срок службы здания. 
УДК 711.581-168, 643.01

Плешкановська А.М., Кузнецова Д.С. Обгрунтування типів застарілого житлового фонду як перший етап ефективної реконструкції // Опір матеріалів і теорія споруд: наук.-тех. збірн. К.: КНУБА, 2021. - Вип. 107. - С. 193-210.

Досліджуються критерії вибору об'єктів жстлового фонду в прочесі реалізачії програми комплексної реконструкиії.

Іл. 3. Бібліогр. 29 назв.

UDC 711.581-168, 643.01

Pleshkanovska A.M., Kuznetsova D.S. Justification of the types of obsolete housing stock as the first stage of effective reconstruction // Strength of Materials and Theory of Structures: Scientificand-technical collected articles. - K.: KNUBA, 2021. - Issue 107. - P. 193-210.

The criteria of the obsolete housing stock determination within complex reconstruction program is considered.

Fig. 3. Ref. 29.

УДК 711.581-168, 643.01

Плешкановская А.М., Кузнеиова Д.С. Обоснование типов устаревшего жилого фонда как первый этап эффективной реконструкции // Сопротивление материалов и теория сооружений: науч.-тех. сборник. - К.: КНУБА, 2021. - Вып. 107. - С. 193-210.

Исследуются критерии выбора объектов жилищного фонда в процессе реализации программы комплексной реконструкиии.

Ил. 3. Библиогр. 29 назв.

Автор (вчена ступень, вчене звання, посада): доктор технічних наук, професор, професор кафедри землеустрою і кадастру ПЛЕШКАНОВСЬКА Алла Михайлівна

Адреса робоча: 03680 Україна, м. Київ, Повітрофлотський проспект, 31, Киӥвський національний університет будівництва і архітектури.

Мобільний тел.: +38(050)334-07-50

Email: pleshkanovska.am@knuba.edu.ua

ORCID 0000-0001-9370-3570

Web of Science ResearcherID: AAD-7119-2019

Scopus Author ID: 57218095248

Автор (вчена ступень, вчене звання, посада): кандидат технічних наук, доцент, доцент кафедри землеустрою і кадастру КУЗНЕЦОВА Дар'я Сергіївна

Адреса робоча: 03680 Україна, м. Київ, Повітрофлотський проспект, 31, Київський національний університет будівництва і архітектури.

Мобільний тел.: +38 (050) 817-0-333

Email: daryakuznetsova@ukr.net

ORCID: 0000-0001-6625-2532

Web of Science ResearcherID: AAC-8732-2019 